\title{
THE GEOMETRY
}

\section{OF}

\section{BINOCULAR SPACE PERCEPTION*}

\author{
by \\ LEGRAND H. HARDY, M.D. \\ GERTRUde RAND, Ph.D. \\ M. CATHERINE RITTLER, B.A. \\ and \\ ALBERT A. BLANK, Ph.D. \\ Mathematical Analyst \\ PAUL BOEDER, Ph.D. \\ Mathematical Consultant
}

From the Knapp Momorial Laboratories, Institute of Ophthalmology, Columbia University College of Physicians and Surgeons, New York 